\title{
Purchase Decision towards Textile and Apparel Products
}

\section{Satheeskumar}

\begin{abstract}
This study is conducted on the purchase decision towards textile and apparel products in Chennai city. It employed both primary and secondary data using various data collection methods. The main objective of this study is, therefore, to study the post-purchase consumer behavior in the study relating to textile and apparel products in study area and offer suitable suggestions and recommendations relating to study on the basis of findings. It was conclude that over all brand loyalty, majority of the respondents satisfied with way in which the brand is marketed is very impressive among entire three regions in brand loyalty of textile and apparel products in Chennai city.
\end{abstract}

Keywords: Apparel; Information search; Promotional offers; Textile; Word-of-mouth.

\section{INTRODUCTION}

The textile industry provides the back - rest for the foreign exchange earning potential of the Indian economy. 'Textiles and clothing constitute nearly 24 per cent of the export in the manufactured goods from India; in other words, out of the total export of US \$35 billion, nearly US \$ 12 billion is earned through export of textile and clothing'(Nair, R, 2003). The market for the Indian textile industry can be broadly classified into three, based or) the sectors of consumption. They are the household sector, the non- household sector (institutional, industrial and technical textiles), and the export sector. 'Among these sectors the household sector consumes approximately 60 per cent, the non house-hold sector consumers 21 per cent, and the export sector accounts for 19 per cent of the total cloth productions (Textiles Committee, 2002).

\section{STATEMENT OF THE PROBLEM}

The consumer is facing difficult to find the information about the products internally and externally. Internal search problem consists of few factors like lack of memory of previous experiences, products, brands, purchased products. External search problem is concern; the following aspects are identified such as: 1.Friends and family 2. Public sources including various product rating organization (i.e., report, other companies comparable data base) 3. Market-dominants (i.e., advertising, company websites and sales forces).

With this above attitudes the researcher is going to study the consumer behavior in textile and apparel products in Chennai city.

\section{OBJECTIVES}

The main object of the present study is retail marketing of textile and apparel products.

To study the Post-Purchase consumer behavior in the study area.

To offer suitable suggestions and recommendations relating to study on the basis of findings.

\section{SCOPE OF THE STUDY}

The present study is a new attempt to outline the behavioral aspects of consumers in the retailing scenario of textile and apparel products in Tamil Nadu. Hence, it will has the sample scope for generating new dimensions of information catering to the requirements of strategic decision making in the sphere of production as well as marketing of textile and apparel products. Among the cities in Tamil Nadu Chennai is top in volume of retail textile and apparel products business in Tamil Nadu. So, the researcher has chosen Chennai city for this proposed study.

\section{METHODOLOGY}

Being a pioneer work, the study is designed to be exploratory. Data are to be collected from consumers and secondary sources. More dependence was on primary source from the consumers in textile and apparel shops.

\section{SAMPLING}

The Chennai city has three Regions namely, North Chennai, Central Chennai and South Chennai. Each of the regions has wards. There are about 200 wards in Chennai city. In order to collect primary data from the customers, the researcher has adopted Multi-stage sampling. At the first stage, 20 wards were selected (10\%) out of 200 wards based on simple random sampling. In the second stage, from each selected wards one Textile and Apparel shop was selected based on convenient sampling. Therefore, twenty shops were selected from 20 wards. At the final stage, 25 customers were selected each from selected shops. Thus, the sample of the study is 500 .

\section{TOOLS FOR COLLATION OF DATA}

The interview schedules will be finalized by conducting a pilot study among 60 consumers of different regions. 


\section{PERIOD OF STUDY}

The data related mainly to a period of 10 year, commencing from 2002-03 to 2017-18, will be collected and made use for the study. Primary data will be collected from the respondents during the year 2017-2018.

\section{TOOLS FOR ANALYSIS}

The data will be analyzed by using various statistical techniques such as Chi-square, Correlation, Factor Analysis, ANOVA have been used with the help of SPSS. To arrive at possible solutions simple percentage analysis was also employed.

\section{STATISTICAL ANALYSIS}

\section{Post Purchase Behaviour}

It is also proposed to examine whether the average level of respondents' perception relating to retail marketing of textile and apparel products are significantly differs among the three regions selected for the study. For this purpose, the ANOVA of one way classification is carried out and the null hypothesis is tested. Hence, H0: (in general) There is no significant difference among the average level of opinion of respondents about the post purchase behaviour with influencing factors of consumer behavior in retail marketing of textile and apparel products in Chennai city.

Table- 1

POST PURCHASE BEHAVIOUR (ANOVA)

\begin{tabular}{|c|c|c|c|c|c|c|}
\hline Variables & ANOVA & Sum of Squares & df & Mean Square & $\mathbf{F}$ & Sig. \\
\hline \multirow{3}{*}{$\begin{array}{l}\text { Purchase at this shop make repeated purchase } \\
\text { since the product is satisfactory }\end{array}$} & Between Groups & 5.903 & 2 & 2.952 & 2.942 & .054 \\
\hline & Within Groups & 498.647 & 497 & 1.003 & & \\
\hline & Total & 504.550 & 499 & & & \\
\hline \multirow{3}{*}{$\begin{array}{l}\text { Reliability and right product information of } \\
\text { the advertisment }\end{array}$} & Between Groups & 5.110 & 2 & 2.555 & 1.644 & .194 \\
\hline & Within Groups & 772.128 & 497 & 1.554 & & \\
\hline & Total & 777.238 & 499 & & & \\
\hline \multirow[t]{3}{*}{ Complaints handling by retailers } & Between Groups & 6.359 & 2 & 3.179 & 3.241 & .040 \\
\hline & Within Groups & 487.553 & 497 & .981 & & \\
\hline & Total & 493.912 & 499 & & & \\
\hline \multirow[t]{3}{*}{ Special care taken by the retailers } & Between Groups & .511 & 2 & .256 & .151 & .860 \\
\hline & Within Groups & 840.567 & 497 & 1.691 & & \\
\hline & Total & 841.078 & 499 & & & \\
\hline \multirow[t]{3}{*}{ Show room advertisement } & Between Groups & 5.164 & 2 & 2.582 & 2.580 & .077 \\
\hline & Within Groups & 497.308 & 497 & 1.001 & & \\
\hline & Total & 502.472 & 499 & & & \\
\hline \multirow[t]{3}{*}{ Product attributes } & Between Groups & 1.678 & 2 & .839 & .568 & .567 \\
\hline & Within Groups & 734.522 & 497 & 1.478 & & \\
\hline & Total & 736.200 & 499 & & & \\
\hline \multirow[t]{3}{*}{ Behaviour of the sales people } & Between Groups & 1.097 & 2 & .548 & .325 & .722 \\
\hline & Within Groups & 837.853 & 497 & 1.686 & & \\
\hline & Total & 838.950 & 499 & & & \\
\hline \multirow[t]{3}{*}{ Quality of the products } & Between Groups & 4.883 & 2 & 2.442 & 1.317 & .269 \\
\hline & Within Groups & 921.667 & 497 & 1.854 & & \\
\hline & Total & 926.550 & 499 & & & \\
\hline
\end{tabular}


International Journal of Recent Technology and Engineering (IJRTE) ISSN: 2277-3878, Volume-8, Issue-2S11, September 2019

\begin{tabular}{|c|c|c|c|c|c|c|}
\hline \multirow[t]{3}{*}{ Design } & Between Groups & 1.430 & 2 & .715 & .723 & .486 \\
\hline & Within Groups & 491.442 & 497 & .989 & & \\
\hline & Total & 492.872 & 499 & & & \\
\hline \multirow[t]{3}{*}{ Durability } & Between Groups & 1.079 & 2 & .539 & .290 & .748 \\
\hline & Within Groups & 924.033 & 497 & 1.859 & & \\
\hline & Total & 925.112 & 499 & & & \\
\hline \multirow[t]{3}{*}{ Price } & Between Groups & 3.376 & 2 & 1.688 & 1.831 & .161 \\
\hline & Within Groups & 458.262 & 497 & .922 & & \\
\hline & Total & 461.638 & 499 & & & \\
\hline \multirow[t]{3}{*}{ Creating friends } & Between Groups & 6.005 & 2 & 3.002 & 1.962 & .142 \\
\hline & Within Groups & 760.353 & 497 & 1.530 & & \\
\hline & Total & 766.358 & 499 & & & \\
\hline \multirow[t]{3}{*}{ Status of the owning product } & Between Groups & 3.215 & 2 & 1.608 & .934 & .394 \\
\hline & Within Groups & 855.607 & 497 & 1.722 & & \\
\hline & Total & 858.822 & 499 & & & \\
\hline
\end{tabular}

\begin{tabular}{|l|c|c|c|c|c|}
\hline $\begin{array}{c}\text { Post } \\
\text { purchase } \\
\text { Behaviour }\end{array}$ & $\begin{array}{c}\text { Sum of } \\
\text { Squares }\end{array}$ & df & $\begin{array}{c}\text { Mean } \\
\text { Square }\end{array}$ & F & Sig. \\
\hline $\begin{array}{l}\text { Between } \\
\text { Groups }\end{array}$ & 1.016 & 2 & .508 & 4.810 & .009 \\
\hline $\begin{array}{l}\text { Within } \\
\text { Groups }\end{array}$ & 52.470 & 497 & .106 & & \\
\hline Total & 53.485 & 499 & & & \\
\hline
\end{tabular}

not significant at 0.05 per cent level.

In over all sense the analysis of variation is highly significant at 0.05 per cent confidence level for the post purchase behaviour factor of the study. The null hypothesis of the study relating to the post purchase behaviour is rejected. It is found that there is a significant variation among average levels of opinion of respondents about "complaints handling by retailers". In other hands all the remaining variables are

Table- 2

BRAND LOYALTY (ANOVA)

\begin{tabular}{|c|c|c|c|c|c|c|}
\hline Variables & ANOVA & $\begin{array}{c}\text { Sum of } \\
\text { Squares }\end{array}$ & df & Mean Square & $\mathbf{F}$ & Sig. \\
\hline \multirow{3}{*}{$\begin{array}{l}\text { The brand chosen has good } \\
\text { reputation }\end{array}$} & Between Groups & 16.495 & 2 & 8.247 & 5.912 & .003 \\
\hline & Within Groups & 693.273 & 497 & 1.395 & & \\
\hline & Total & 709.768 & 499 & & & \\
\hline The way in which the brand is & Between Groups & 1.011 & 2 & .506 & .350 & .705 \\
\hline
\end{tabular}

BRAND LOYALTY

It is also proposed to examine whether the average level of respondents' perception relating to retail marketing of textile and apparel products are significantly differs among the three regions selected for the study. For this purpose, the ANOVA of one way classification is carried out and the null hypothesis is tested. Hence, H0: (in general) There is no significant difference among the average level of opinion of respondents about the brand loyalty with influencing factors of consumer behavior in retail marketing of textile and apparel products in Chennai city. 
PURCHASE DECISION TOWARDS TEXTILE AND APPAREL PRODUCTS

\begin{tabular}{|c|c|c|c|c|c|c|}
\hline \multirow{2}{*}{ marketed is very impressive } & Within Groups & 717.187 & 497 & 1.443 & & \\
\hline & Total & 718.198 & 499 & & & \\
\hline \multirow{3}{*}{$\begin{array}{l}\text { I will stick to the same brand } \\
\text { in future }\end{array}$} & Between Groups & .111 & 2 & .056 & .026 & .974 \\
\hline & Within Groups & 1049.527 & 497 & 2.112 & & \\
\hline & Total & 1049.638 & 499 & & & \\
\hline \multirow{3}{*}{$\begin{array}{l}\text { I can adjust with the } \\
\text { shortcomings of the brand, if } \\
\text { any }\end{array}$} & Between Groups & .460 & 2 & .230 & .235 & .791 \\
\hline & Within Groups & 486.548 & 497 & .979 & & \\
\hline & Total & 487.008 & 499 & & & \\
\hline \multirow{3}{*}{$\begin{array}{l}\text { I do not tolerate the } \\
\text { non-availability of the brand }\end{array}$} & Between Groups & 1.696 & 2 & .848 & .599 & .550 \\
\hline & Within Groups & 703.462 & 497 & 1.415 & & \\
\hline & Total & 705.158 & 499 & & & \\
\hline \multirow{3}{*}{$\begin{array}{l}\text { I am enjoying because using } \\
\text { this brand }\end{array}$} & Between Groups & 5.374 & 2 & 2.687 & 2.008 & .135 \\
\hline & Within Groups & 664.888 & 497 & 1.338 & & \\
\hline & Total & 670.262 & 499 & & & \\
\hline \multirow{3}{*}{$\begin{array}{l}\text { I appreciate those who use the } \\
\text { same brand }\end{array}$} & Between Groups & 28.774 & 2 & 14.387 & 8.613 & .000 \\
\hline & Within Groups & 830.128 & 497 & 1.670 & & \\
\hline & Total & 858.902 & 499 & & & \\
\hline \multirow{3}{*}{$\begin{array}{l}\text { I share my views about the } \\
\text { brand with others }\end{array}$} & Between Groups & .235 & 2 & .117 & .075 & .928 \\
\hline & Within Groups & 776.613 & 497 & 1.563 & & \\
\hline & Total & 776.848 & 499 & & & \\
\hline \multirow{3}{*}{$\begin{array}{l}\text { Will have discussions with } \\
\text { friends to popularize the shop }\end{array}$} & Between Groups & .417 & 2 & .208 & .130 & .878 \\
\hline & Within Groups & 797.935 & 497 & 1.606 & & \\
\hline & Total & 798.352 & 499 & & & \\
\hline \multirow{3}{*}{$\begin{array}{l}\text { Want others to realize the } \\
\text { name of the shop }\end{array}$} & Between Groups & 2.259 & 2 & 1.129 & .910 & .403 \\
\hline & Within Groups & 617.093 & 497 & 1.242 & & \\
\hline & Total & 619.352 & 499 & & & \\
\hline \multirow{3}{*}{$\begin{array}{l}\text { Won't switch over to other } \\
\text { shops if my brand is not } \\
\text { available }\end{array}$} & Between Groups & .092 & 2 & .046 & .033 & .967 \\
\hline & Within Groups & 686.908 & 497 & 1.382 & & \\
\hline & Total & 687.000 & 499 & & & \\
\hline
\end{tabular}

\begin{tabular}{|l|c|c|c|c|c|}
\hline \multicolumn{1}{|c|}{$\begin{array}{c}\text { Brand } \\
\text { Loyalty }\end{array}$} & $\begin{array}{c}\text { Sum of } \\
\text { Squares }\end{array}$ & df & $\begin{array}{c}\text { Mean } \\
\text { Square }\end{array}$ & F & Sig. \\
\hline $\begin{array}{l}\text { Between } \\
\text { Groups }\end{array}$ & 1.043 & 2 & .521 & 3.197 & .042 \\
\hline $\begin{array}{l}\text { Within } \\
\text { Groups }\end{array}$ & 81.064 & 497 & .163 & & \\
\hline Total & 82.107 & 499 & & & \\
\hline
\end{tabular}

In over all sense the analysis of variation is highly significant at 0.05 per cent confidence level for the brand loyalty factor of the study. The null hypothesis of the study relating to the brand loyalty is rejected. It is found that there is a significant variation among average levels of opinion of respondents about "brand chosen has good reputation" and "I appreciate those who use the same brand". In other hands all the remaining variables are not significant at 0.05 per cent level. 


\section{CORRELATIONS}

Table - 3

\begin{tabular}{|c|c|c|c|c|c|c|c|c|}
\hline \multicolumn{9}{|c|}{ Correlations } \\
\hline & & $\begin{array}{c}\text { Need } \\
\text { Recognition }\end{array}$ & $\begin{array}{l}\text { Sources of } \\
\text { information }\end{array}$ & $\begin{array}{c}\text { Purchase } \\
\text { Alternatives }\end{array}$ & $\begin{array}{c}\text { Factors } \\
\text { Influencing } \\
\text { Purchase }\end{array}$ & \begin{tabular}{|c|} 
At the \\
time of \\
purchase
\end{tabular} & \begin{tabular}{|c|} 
Post \\
Purchase \\
Behaviour
\end{tabular} & $\begin{array}{l}\text { Brand } \\
\text { Loyalty }\end{array}$ \\
\hline \multirow{3}{*}{$\begin{array}{l}\text { Post Purchase } \\
\text { Behaviour }\end{array}$} & $\begin{array}{l}\text { Pearson } \\
\text { Correlation }\end{array}$ & .073 & .042 & .022 & .010 & .056 & 1 & -.003 \\
\hline & Sig. (2-tailed) & .101 & .348 & .617 & .818 & .215 & & .951 \\
\hline & $\mathrm{N}$ & 500 & 500 & 500 & 500 & 500 & 500 & 500 \\
\hline \multirow{3}{*}{ Brand Loyalty } & $\begin{array}{l}\text { Pearson } \\
\text { Correlation }\end{array}$ & $.103(*)$ & $.091(*)$ & $.129(*)$ & $.111(*)$ & $.100(*)$ & -.003 & 1 \\
\hline & Sig. (2-tailed) & .022 & .041 & .004 & .013 & .026 & .951 & \\
\hline & $\mathrm{N}$ & 500 & 500 & 500 & 500 & 500 & 500 & 500 \\
\hline
\end{tabular}

The above Table shows the correlations of various factors of consumer behavior in retail marketing of textile and apparels products like "post purchase behaviour", "brand loyalty". The correlation between brand loyalty and need recognition was .103 which was positively correlated and significant at 0.05 per cent level, correlation between brand loyalty and sources of information was .091 which was positively correlated significant at 0.05 per cent level, The correlation between brand loyalty and purchase alternatives was .129 which was positively correlated and significant at 0.05 per cent level, correlation between brand loyalty and factors influencing purchases was .111 which was positively correlated significant at 0.05 per cent level, correlation between brand loyalty and at the time of purchases was .100 which was positively correlated significant at 0.05 per cent level.

\section{SOURCES OF INFORMATION (FACTOR ANALYSIS) \& RESULTS}

\section{Post Purchase Behaviour}

The factor analysis is made for the contribution of variables belongs to the post purchase behaviour providers in the study area given in the following tables.

Table No.4

Descriptive Statistics of Factors influences Purchase Decisions

\begin{tabular}{|l|c|c|c|}
\hline \multicolumn{1}{|c|}{ Variables } & Mean & Std. Deviation & Analysis N \\
\hline $\begin{array}{l}\text { Purchase at this shop make repeated purchase } \\
\text { since the product is satisfactory }\end{array}$ & 3.03 & 1.006 & 500 \\
\hline $\begin{array}{l}\text { Reliability and right product information of the } \\
\text { advertisement }\end{array}$ & 3.72 & 1.248 & 500 \\
\hline Complaints handling by retailers & 4.28 & .995 & 500 \\
\hline Special care taken by the retailers & 3.94 & 1.298 & 500 \\
\hline Show room advertisement & 2.92 & 1.003 & 500 \\
\hline Product attributes & 4.14 & 1.215 & 500 \\
\hline Behaviour of the sales people & 3.89 & 1.297 & 500 \\
\hline
\end{tabular}


PURCHASE DECISION TOWARDS TEXTILE AND APPAREL PRODUCTS

\begin{tabular}{|l|c|c|c|}
\hline Quality of the products & 2.17 & 1.363 & 500 \\
\hline Design & 4.52 & .994 & 500 \\
\hline Durability & 3.92 & 1.362 & 500 \\
\hline Price & 1.42 & .962 & 500 \\
\hline Creating friends & 4.28 & 1.239 & 500 \\
\hline Status of the owning product & 1.93 & 1.312 & 500 \\
\hline
\end{tabular}

Source: Computed primary data

The table above is output of the univariate option on the selected variables of the factor. The number of cases used in the analysis is 500 respondents. The factor analysis is being

Table No.5

Total Variance Explained about Post Purchase Behaviour

\begin{tabular}{|c|c|c|c|c|c|c|}
\hline \multirow{2}{*}{ Component } & \multicolumn{5}{|c|}{ Initial Eigen values } & \multicolumn{2}{c|}{ Extraction Sums of Squared Loadings } \\
\cline { 2 - 7 } & Total & \% of Variance & Cumulative \% & Total & \% of Variance & Cumulative \% \\
\hline 1 & 1.398 & 10.752 & 10.752 & 1.398 & 10.752 & 10.752 \\
\hline 2 & 1.272 & 9.784 & 20.536 & 1.272 & 9.784 & 20.536 \\
\hline 3 & 1.180 & 9.075 & 29.611 & 1.180 & 9.075 & 29.611 \\
\hline 4 & 1.127 & 8.668 & 38.279 & 1.127 & 8.668 & 38.279 \\
\hline 5 & 1.060 & 8.154 & 46.433 & 1.060 & 8.154 & 46.433 \\
\hline 6 & 1.051 & 8.088 & 54.521 & 1.051 & 8.088 & 54.521 \\
\hline 7 & .998 & 7.678 & 62.199 & & & \\
\hline 8 & .940 & 7.230 & 69.428 & & & \\
\hline 9 & .924 & 7.105 & 76.533 & & & \\
\hline 10 & .856 & 6.582 & 83.115 & & & \\
\hline 11 & .779 & 5.989 & 89.104 & & & \\
\hline 12 & .728 & 5.597 & 94.701 & & & \\
\hline 13 & .689 & 5.299 & 100.000 & & & \\
\hline
\end{tabular}

Source: Computed primary data

The initial number of factors is the same as the number of variables used in the factor analysis. However, all 13 variables have not been retained. In this analysis, only the first right variables have been retained. Eigen values are the variances of the variables. Because the principal component analysis on the correlation matrix, the variables are standardized, which means that each variable has a variance of 1 , and the total variance is equal to the number of variables used in the analysis, in this case, 13. The first set of conducted on the correlations (as opposed to the covariances), it is not much of a concern that the variables have very different means and/or standard deviations (which is often the case when variables are measured on different scales). 
Table No.6

Factor Matrix of the Post Purchase Behaviour

\begin{tabular}{|c|c|c|c|c|c|c|}
\hline \multicolumn{2}{|c|}{ Variables } & \multicolumn{5}{c|}{ Component } \\
\cline { 2 - 7 } & $\mathbf{1}$ & $\mathbf{2}$ & $\mathbf{3}$ & $\mathbf{4}$ & $\mathbf{5}$ & $\mathbf{6}$ \\
\hline $\begin{array}{c}\text { Purchase at this shop make repeated purchase } \\
\text { since the product is satisfactory }\end{array}$ & .055 & .140 & -.482 & .276 & .631 & .213 \\
\hline Reliability and right product information of the & .538 & .096 & -.081 & -.139 & .052 & -.182 \\
\hline $\begin{array}{c}\text { advertisment } \\
\text { Complaints handling by retailers }\end{array}$ & -.135 & .013 & -.443 & .189 & -.241 & -.553 \\
\hline Special care taken by the retailers & .206 & -.408 & .391 & .392 & .435 & -.020 \\
\hline Show room advertisement & .344 & .311 & -.079 & -.078 & .219 & -.255 \\
\hline Product attributes & .243 & .547 & .075 & .271 & -.125 & .014 \\
\hline Behaviour of the sales people & .049 & -.006 & .626 & -.292 & .159 & -.294 \\
\hline Quality of the products & -.366 & .198 & .102 & -.367 & .208 & .313 \\
\hline Design & .156 & .622 & .221 & .028 & -.251 & .233 \\
\hline Durability & .073 & -.136 & -.345 & -.605 & .036 & .241 \\
\hline Price & -.081 & -.192 & .054 & .398 & -.326 & .469 \\
\hline Creating friends & .663 & -.028 & -.033 & -.029 & .022 & .289 \\
\hline Status of the owning product & -.505 & .445 & .073 & .125 & .329 & -.044 \\
\hline
\end{tabular}

Source: Computed primary data

The above table infers that the factors post purchase behaviour provided by the consumer behaviour in retail marketing in textile and apparel products in the aspects of "quality", "celebrity", "seller's convincing style", "varieties" and "parent's style" have been highly contributed in the first set of components than other, the second thing is "learning from various sources", "free complements" and "envy". The third set of components contributed on "friend's compulsion", the fourth set of components contributed on "advertisement", "location of the shop" and "income", the fifth set of components contributed on "colour", the sixth set of components contributed on "size". Thus, the respondents satisfaction pertaining to the need recognition is highly contributed from the above six sets of components such as "quality", "celebrity", "seller's convincing style", "varieties" and "parent's style".

\section{FINDINGS}

1. Purchase at this shop make repeated purchase since the product is satisfactory 55.3 percent of the respondents neither satisfied nor dissatisfied and also 3.3 percent of the respondents highly satisfied with North Chennai among three regions in Chennai city.

2. 40.7 percent of the respondents highly satisfied in South Chennai and only 4.0 percent of the respondents highly dissatisfied with reliability and right product information of the advertisement in North Chennai among entire three regions in Chennai city.
3. Among the three regions majority (62.0 percent) of the respondents highly satisfied in North Chennai and only 1.3 percent highly dissatisfied with complaints handling by retailers in the aspects of the textile and apparel products in Central Chennai.

4. Special care taken by the retailers 52.7 percent of the respondents highly satisfied in North Chennai and only 6.7 percent of the respondents dissatisfied with South Chennai among three regions in Chennai city.

5. 66.0 percent of the respondents neither satisfied nor dissatisfied in North and Central Chennai and only 3.0 percent of the respondents dissatisfied with show room advertisement in Central Chennai among entire three regions in Chennai city.

6. Among the three regions majority (61.0 percent) of the respondents highly satisfied in Central Chennai and also 4.5 percent highly dissatisfied with product attributes in the aspects of the textile and apparel products in Central Chennai.

7. Behaviour of the sales people 48.5 percent of the respondents highly satisfied in Central Chennai and only 5.3 percent of the respondents dissatisfied with North Chennai among three regions in Chennai city. 
8. 47.0 percent of the respondents highly dissatisfied in Central Chennai and only 5.0 percent of the respondents satisfied with quality of the products in Central Chennai among entire three regions in Chennai city.

9. Among the three regions majority ( 74.7 percent) of the respondents highly satisfied in South Chennai and also 2.0 percent neither satisfied nor dissatisfied with design of the textile and apparel products in Central Chennai.

10. Regarding durability of the respondents 54.5 percent highly satisfied and also only 6.0 percent of the respondents neither satisfied nor dissatisfied with Central Chennai among three regions in Chennai city.

11. 84.0 percent of the respondents highly dissatisfied in Central Chennai and only 1.5 percent of the respondents satisfied with price of the products in Central Chennai among entire three regions in Chennai city.

12. Among the three regions majority (74.0 percent) of the respondents highly satisfied in South Chennai and only 4.0 percent neither satisfied nor dissatisfied with creating friends of the textile and apparel products in Central and South Chennai.

13. Regarding Status of the owning product of the respondents 63.3 percent highly dissatisfied with North and South Chennai and also only 1.3 percent of the respondents highly dissatisfied with North Chennai among three regions in Chennai city.

14. In over all sense the analysis of variation is highly significant at 0.05 per cent confidence level for the post purchase behaviour factor of the study. The null hypothesis of the study relating to the post purchase behaviour is rejected. It is found that there is a significant variation among average levels of opinion of respondents about "complaints handling by retailers". In other hands all the remaining variables are not significant at 0.05 per cent level.

15. The null hypothesis of the study relating to the brand loyalty is rejected. It is found that there is a significant variation among average levels of opinion of respondents about "brand chosen has good reputation" and "I appreciate those who use the same brand". In other hands all the remaining variables are not significant at 0.05 per cent level.

16. The correlation between brand loyalty and need recognition was .103 which was positively correlated and significant at 0.05 per cent level, correlation between brand loyalty and sources of information was .091 which was positively correlated significant at 0.05 per cent level, The correlation between brand loyalty and purchase alternatives was .129 which was positively correlated and significant at 0.05 per cent level, correlation between brand loyalty and factors influencing purchases was .111 which was positively correlated significant at 0.05 per cent level, correlation between brand loyalty and at the time of purchases was .100 which was positively correlated significant at 0.05 per cent level.

17. the respondents satisfaction pertaining to the post purchase behaviour is highly contributed from the above six sets of components such as "quality", "celebrity", "seller's convincing style", "varieties" and "parent's style".

18. Brand loyalty average 34.17 percent of the respondents highly satisfied and also 13.95 percent of the respondents neither agree nor disagree in North Chennai, 31.32 percent of the respondents highly satisfied and also 13.45 percent of the respondents neither agree nor disagree in Central Chennai and 31.09 of the respondents highly satisfied and also 12.85 percent of the respondents neither agree nor disagree in South Chennai.

19. In the range of 43.94 percent to 48.12 percent of the respondents were satisfied, 12.85 percent to 13.95 percent of the respondents were neutral and 34.12 percent to 37.14 percent of the respondents were dissatisfied with overall brand loyalty.

\section{SUGGESTIONS}

Regarding purchase at this shop make repeated purchase since the product is satisfactory and show room advertisement majority of the respondents neither satisfied nor dissatisfied and only few percentages highly satisfied. Usually majority of elder people purchase the products in the same retailer shops if satisfied and in the young age group they change their purchase from one shop to another. If a shop provides good quality, low price, more design and variety, trade discount and new fashion it leads to retain the elder and younger age groups and capture the new customers also.

Quality of the products, price and Status of the owning product majority of the respondents highly dissatisfied with the post purchase behaviour of textile and apparels products in Chennai city. In the competitive world the retailers should give the high quality of the products at reasonable rates it leads to high income consumers purchase the quality aspects and middle income consumers also purchase the products for reasonable rates and to satisfied the status of owning the product, consumers and retailers should aware about recent trend in the market in the way of stylish and new fashion otherwise consumers may switch over to other retailers.

Regarding reliability and right product information of the advertisement, complaints handling by retailers, special care taken by the retailers, product attributes, behaviour of the sales people, design and durability majority of the respondents were highly satisfied. In the post purchase behaviour aspect the retailer should retain the highly satisfied consumers and try to convince the dissatisfied consumers. 


\section{CONCLUSION}

The post purchase behaviour regarding textile and apparel products are important factors that need to be determined in order to understand consumers better and to improve consumers' satisfaction of textile and apparel products. This present study explores consumers' post purchase behaviour towards retail marketing on textile and apparel products by addressing the perceptual process. It was conclude that over all brand loyalty, majority of the respondents satisfied with way in which the brand is marketed is very impressive among entire three regions in brand loyalty of textile and apparel products in Chennai city.

\section{REFERENCES}

1. Bayton, James, A., Motivation, Cognition, Learning -Basic Factors in Consumer Behaviour, Journal of Marketing, January 195 8,P- 16.

2. Becker, Garry S., A Theory of Allocation of Time, Economic Journal, May 1965,P-493.

3. Beijer, G., Demographic, Social and Economic Aspects of Internal Migration in Some European Countries, United Nations World Population Congress, Belgrade, 1965,P- 190.

4. Belch, A., Michael and Belch E, George., Advertising and Promotion. Irwin Homewood, Boston, 1993,P-463,506,523,529,532.

5. Bennet, Peter D., Consumer Behaviour, Prentice - Hall, Engel Cliff, New Jersy, 1988 P-114.

6. Casteless, M.The Information Age, Society and Culture, Oxford Blackwell, 1996,P- 18.

7. Chatterjee, Dehojoti, Open Season and Regional Brand, Business Today, May2001, New Delhi, P-35.

8. Chisnall, Peter, M., Marketing -A Behavioural Analysis Mc Graw -Hill Book Company London, 1985, P 141.

9. Cowan, M.L and Jungerman, M.E., Introduction to Textiles, D.B Tharapurvala and Sons and Co., Bombay, 1980, P-50.

10. Hulland, Johans., The Effvct of Brand and Brand Name on Product Evaluation and Consideration, A cross Country Comparison, Consumer Behaviour in Asia, 1999, P-23.

11. John, Philip, Jones., What is in a Brand- Building Brand Equity Through, Advertising, Tata Mc. Graw- Hill Publishing Co., New Delhi, 1988 ,P-62. 